\title{
Encanto desde Hollywood: glamour y feminidad en la revista Ecran (Chile 1930-1931)
}

\section{Charming from Hollywood: Glamour and femininity in the magazine Ecran (Chile 1930-1931)}

\author{
Andrea Robles Parada \\ Facultad de Humanidades, Universidad de Valparaíso. Valparaíso, Chile. \\ andreaisolroblesp@gmail.com
}

\section{Resumen}

El objetivo del artículo es dar cuenta de las representaciones de género de las estrellas hollywoodense en la revista chilena Ecran en los años 1930-1931. Durante toda la década del treinta, el atractivo de Hollywood ayudó a consolidar una cultura de masas en Chile, popularizando una modernidad al estilo norteamericano. En este contexto, se indaga cómo la imagen de la estrella en Ecran operó a modo de una representación de género que se instaló como un referente de la mujer moderna y elegante. Planteamos que las estrellas publicitadas por la revista representaron una feminidad glamorosa con un importante valor estético asociado a parámetros corporales y de apariencia como la delgadez y la moda.

Palabras clave: representación de género, revistas de cine, estrellas de Hollywood, moda.

\begin{abstract}
The objective of this article is to account for gender representations about the female stars in the Chilean magazine Ecran, during the years 1930-1931. During the 30s, the lure of Hollywood stars helped to consolidate a mass culture in Chile, popularizing a modern American style. In this context, it is investigated how the image of the Hollywood star in Ecran operated as a gender representation and was installed as a benchmark for modern and elegant woman. In this regard, we propose that the Hollywood stars publicized in Ecran represented a glamorous femininity with an important aesthetic value concerning body and appearance parameters as thinness and fashion.
\end{abstract}

Keywords: Gender Representation, Film Magazines, Hollywood Stars, Fashion.

1 Este trabajo es resultado del proyecto FONDECYT regular no 1151112 , en el marco del Convenio de Desempeño para las Humanidades, Artes y Ciencias Sociales de la Universidad de Valparaíso. 


\section{Introducción}

Los retratos de Greta Garbo, Norma Shearer y Marlene Dietrich fueron publicados reiteradamente en las páginas de la revista Ecran, potenciando en Chile la fascinación del público por las estrellas de cine. No en vano, el periodista Raúl Cuevas describió en la misma revista que: "Cuando vamos al cine siempre nos quedamos enamorados de alguna hermosa artista" (28). Desde la década de 1920, el sistema del estrellato involucró una red en la que el contenido, la realización y la publicidad de las películas norteamericanas comenzaron a gravitar alrededor de las estrellas (Morin 6). Paralelamente, la seducción de este nuevo medio y sus protagonistas potenció el desarrollo de revistas especializadas en cine y espectáculo. Estas asumieron el papel de formar e ilustrar al público en el lenguaje propio del soporte fílmico y, a su vez, fueron cómplices del sistema del estrellato al promocionar las excentricidades de la vida íntima de actrices y actores (Ossandón, "Los mudos rostros" 120). Desde su aparición en abril de 1930, la revista chilena Ecran se sumó al sistema del estrellato desempeñando un periodismo cinematográfico que fijó la equivalencia entre cine y Hollywood. Más aun, la publicación de noticias sobre las estrellas -como sus nuevas películas, los vaivenes de su vida amorosa y la difusión de sus fotografías- ayudó a que ellas se fueran "grabando en la retina y en la memoria de los lectores" chilenos (Mouesca 64-5).

La importación del cine de Hollywood en Chile y en Latinoamérica no fue algo casual, sino que se insertó dentro de la política norteamericana de expandir su estilo de vida y mercado al resto del mundo (Purcell, ;De película!). Esta "norteamericanización" ofreció la posibilidad de integrarse a la modernidad a partir de la difusión de una creciente producción de imágenes visuales transferidas por los medios masivos (Rinke, Encuentros con el yanqui 36). Así, entre las décadas de 1910 y 1930, la consolidación de una cultura de masas en Chile contempló la introducción de toda una maquinaria representacional de una modernidad al estilo norteamericano (Purcell, "Una mercancía irresistible" 64). Estas representaciones, especialmente las de las estrellas hollywoodenses, se fueron transformando un referente del modelo de la mujer moderna entre las espectadoras chilenas.

El objetivo del presente artículo es dar cuenta de cómo las imágenes de las estrellas de Hollywood difundidas en Ecran actuaron como una representación de género, en el contexto del proceso de norteamericanización de los valores culturales en la sociedad chilena. En este sentido, es posible afirmar que Ecran funcionó como una tribuna que puso en circulación la representación de una feminidad glamorosa en torno a las actrices hollywoodenses. Dicha representación incluyó, por una parte, la construcción de una actitud atrevida y de una personalidad auténtica y seductora sobre la imagen encantadora, sofisticada y carismática de las estrellas. Por otra parte, comprendió un importante valor estético asociado a parámetros corporales y de apariencia como la delgadez, la actividad física y el uso de vestuarios más osados para la época. 
Desde los aportes de la teoría de las representaciones sociales y la teoría feminista, concebimos las representaciones de género como las ideas, afirmaciones, significados y figuraciones basadas en las diferencias sexuales que se traducen en las categorías de feminidad y masculinidad. La socióloga Denise Jodelet define las representaciones sociales como una forma de pensamiento social, una manera de interpretar y pensar la realidad cotidiana ("La representación social" 473). De tal manera, las representaciones sociales como categoría de análisis y teoría constituyen un tipo de conocimiento a partir del cual se elaboran los esquemas organizadores y las referencias que ordenarán la vida social (Jodelet, "Representaciones sociales" 16-7). Estos esquemas involucran tres tipos de lógicas: biológica y sexual, reproducida en los sistemas de clasificación binaria; referencial, que introduce el lugar de las relaciones sociales y de poder; y cronológica, referida a la inscripción de los acontecimientos en la historia de los individuos y los grupos (20). Este enfoque concibe el género y la diferencia sexual como un componente central en la construcción de las representaciones sociales y, por ende, en la organización de la vida social. Por su parte, desde la teoría feminista, Teresa de Lauretis (2000) señala que el sistema sexo-género se compone de representaciones que asignan significados - de identidad, valor, prestigio, ubicación en la jerarquía, etc. - a los individuos en la sociedad. Así, ser representado y representarse como varón o mujer implica asumir la totalidad de los efectos de esos significados (39). A su vez, para Joan Scott, en las representaciones de género intervienen relaciones de poder que legitiman una jerarquización binaria y espacios de interacción para hombres y mujeres. Así, las representaciones de género están cargadas de figuraciones que establecen un horizonte normativo sobre la feminidad y masculinidad, pero al mismo tiempo estas son desbordadas por definiciones alternativas, disfrazadas o suprimidas.

La feminidad que desplegó la estrella de cine contó con un componente comercial y con otro estético. En el primer caso, las estrellas, como señaló Richard Dyer, son una forma de capital de inversión de los estudios cinematográficos para mantener un mercado formado por públicos interesados. De hecho, el propio sistema del estrellato puede considerarse una industria cultural que opera mediante la construcción del aura seductora de las estrellas (Benavente). El estrellato, en tanto producto de la industria cultural, influye notoriamente en lo social, lo cultural y lo económico más allá de las fronteras norteamericanas, sobre todo al implicar la representación de la vida moderna. En este sentido, la modernidad, como trasformación de época, tensiona las ideas, vivencias y discursos tradicionales, para sustentar nuevas formas de vivir la experiencia moderna (Berman). Entre esas vivencias y discursos se encuentra la experiencia del género. Para el caso del estrellato, las actrices norteamericanas representaron un modelo mediático de vivir la modernidad y representar la feminidad, cuando el estatus de "chica moderna" se volvió una obsesión social (Dyhouse 19). Por su parte, la carga estética de las estrellas de Hollywood se desarrolló a través del discurso visual de la moda, la elegancia y el cuerpo cuidado y esbelto, es decir, el glamour como representación de una feminidad moderna. 
El cuerpo documental utilizado para esta investigación corresponde a los 26 números del primer año de circulación de Ecran, publicados entre abril de 1930 y marzo de 1931. Se consideraron para su análisis las secciones permanentes, los artículos, la publicidad y, especialmente, las fotografías. Esto se tradujo metodológicamente en un enfoque cualitativo con una aproximación interdisciplinaria, que incluyó análisis de contenido, análisis de discurso y análisis estético. Con ello, pretendemos acercarnos a la perspectiva multimodal de la revista (Serafini), es decir, la interacción y colaboración del texto escrito y las imágenes visuales.

\section{El cine hollywoodense, la cultura de la mirada y la revista Ecran}

En Chile, el gusto por el cine comenzó a masificarse recién en la década de 1910 (Santa Cruz, "El nuevo arte"), y para 1913 Santiago ya contaba con 51 salas de cine de diferente calidad y confort. Antes de ello, era considerado un espectáculo plebeyo, indigno de las clases cultas, lo que cambió después de la Primera Guerra Mundial, cuando las películas adquirieron mayor calidad (Mouesca y Orellana 27). Asimismo, este conflicto bélico marcó un importante cambio en el tipo de producciones fílmicas que llegaban al país: la industria del cine norteamericano lo aprovechó para desplazar a la producción europea y controlar el mercado, conquistando "cómodamente unas posiciones comerciales y una primacía industrial" (Gubern 153). Para la década de 1920, "los grandes consorcios de EEUU tomaron la decisión de instalar oficinas propias en diversos países latinoamericanos, para realizar directamente la distribución de sus películas" (Santa Cruz, 2005: 211). En Santiago se instalaron las oficinas de la Paramount, la United Artists y la Metro Goldwyn Mayer.

La simpatía del público chileno para con el imaginario estadounidense que difundía Hollywood contrastaba con la compleja situación económica y política del país a raíz de la depresión económica desatada en 1929. La interrupción de los préstamos que Chile recibía de los Estados Unidos condujeron al país a una paralización económica que dejó en evidencia la dependencia local del mercado internacional (Correa et. al 106). Debido a esto, la sociedad chilena se debatió entre el rechazo a la norteamericanización económica, que fue entendida como el origen de la catástrofe, y la apropiación de este discurso por parte de grupos sociales más extensos. En este contexto, "los yanquis, simbólicos y reales, adquirieron el carácter de chivo expiatorio" (Rinke, Encuentros con el yanqui 267). Paradójicamente, a pesar de ser otro espacio de la norteamericanización, el cine hollywoodense y su irresistible poder mercantil no fue rechazado.

De acuerdo con Román Gubern, la atracción ejercida por el cine hollywoodense del periodo se sustentó en dos pilares: su estilo narrativo ${ }^{2}$ y el sistema del estrellato

2 La eficacia del estilo narrativo se basó en los “esquemas mitológicos más elementales, con películas de «buenos y malos», persecuciones y tiroteos, angustias y final feliz” (Gubern 155). 
basado en la transferencia emotiva que se sustentó en el proceso cuasi hipnótico que operaba durante el ritual de la proyección cinematográfica (139-40). La expresión que tomó la fascinación por el cine y las estrellas fue el enamoramiento, tal como lo manifestó la prensa chilena en 1918: "Verdaderamente amamos a los artistas cinematográficos, apasionadamente, con entusiasmo casi loco. [...] Todo el mundo quiere ir al biógrafo. Hay tantas artistas bonitas y elegantes en el cine, que nos atraen y cautivan" (Eliot 6).

Este enamoramiento por las estrellas no solo se fabricó a través de las películas, sino que fue reforzado por la prensa, la que se desempeñó como su medio de propaganda (Dyer 87). En el caso de Chile, las revistas magazinescas, en un primer momento, y luego las de cine y espectáculo, alimentaron y acercaron el estrellato norteamericano al público local. Por ejemplo, la revista Zig-Zag (1905-1964) paulatinamente y desde su fundación publicó notas sobre cine, para luego, en la década de 1920, sumarse a la explosión de imágenes y noticias proveniente del circuito hollywoodense (Faúndez).

Habría que mencionar además que entre 1915 y 1920 se publicaron por lo menos ocho revistas dedicadas al cine y al teatro (Santa Cruz, "Las revistas de cine" 215). Este tipo de revistas cumplió un doble papel en la irrupción del atractivo de Hollywood en la escena nacional. Por una parte, colaboró estrechamente con la expansión del mercado de la industria cinematográfica (Santa Cruz, 2004) y, por otra, facilitó el posicionamiento de Hollywood, en desmedro del cine europeo, en el gusto de los espectadores chilenos (Purcell, ;De película! 59).

La primera revista que apareció en Chile dedicada exclusivamente al cine fue $\mathrm{La}$ semana cinematográfica (1918-1920). En sus páginas, era posible encontrar la cartelera, los argumentos de las películas, información sobre la remodelación e inauguración de las salas, fotografías de actrices y actores del momento e información sobre las casas importadoras y distribuidoras de filmes (Santa Cruz, "Cultura de masas"). Su directora, Lucila Azagra, se destacó por su visionaria concepción del mercado cinematográfico, posicionándose como una de las más fieras defensoras del cine como empresa comercial, expresión artística y símbolo de modernización (Montero 69). La semana cinematográfica se convirtió en la precursora de la revista de cine en Chile (Bongers 159), formato que fue continuado más tarde por las revistas Hollywood (1926-1928), Crítica (1929-1930) y Ecran (1930-1969).

La editorial Zig-Zag emprendió la publicación de la revista Ecran cuando, ante la novedad del cine hablado y sonoro ${ }^{3}$, el cine en general comenzó a tomar una mayor relevancia entre el público chileno. El estatus de espectáculo masivo que el cine alcanzó en Chile durante esa década coincidió con la "edad de oro de Hollywood" (Iturriaga). La revolución tecnológica del cine hablado atrajo más al público local

3 En 1927, en el Teatro Carrera de Santiago, se proyectó La melodía de Broadway, la primera película sonora, mientras que en el Teatro Victoria se estrenó El cantor de Jazz, la primera película hablada. Hasta ese momento, las películas mudas eran acompañadas con música proveniente de discos que se tocaban en una victrola oculta entre bastidores. 
a las salas, interesado en escuchar hablar por primera vez a sus estrellas favoritas ${ }^{4}$. A su vez, terminó por consolidarlo como una importante oferta cultural que se incluyó entre las actividades sociales de la juventud de clase alta y media chilena ${ }^{5}$. El afianzamiento del cine hollywoodense en el público chileno fue utilizado por Ecran para publicitar a las estrellas del momento. Es más, Ecran estrechó su vínculo con Hollywood gracias a su doble dirección: el director de cine Carlos Borcosque se encargó de enviar crónicas, entrevistas y material fotográfico de gran calidad desde Hollywood, mientras que el periodista y antiguo redactor de teatro de El Mercurio, Roberto Aldunate, funcionó como un segundo director encargado de las informaciones nacionales y, especialmente, de la edición de cada número. De este modo, Ecran se posicionó como vaso comunicante entre el star system hollywoodense y el público espectador/lector ${ }^{6}$.

Sin embargo, ha de destacarse que el formato de Ecran fue ambiguo. Al incluir secciones como "Últimos estrenos" y "Chismografía" junto a otras como "Página de la mujer" y retratos de "Bellezas chilenas", lo que hizo fue combinar géneros, transitando "entre una publicación cinematográfica y lo que entonces se entendía por revista «femenina»" (Mouesca 72). El formato de revista femenina comporta una doble significancia: primero, la disposición de contenidos busca llegar mayormente a un público femenino; $y$, segundo, estos " $\mathrm{da}[\mathrm{n}]$ cuenta y establece[n] pautas de comportamiento y modelos de referencia" (Gallego 21). Tradicionalmente, las revistas femeninas han reforzado la socialización diferencial de las mujeres, reproduciendo y manteniendo en sus páginas los estereotipos de género (Méndez) 7 . En Ecran, tales estereotipos tomaron la forma de una feminidad glamorosa y una masculinidad seductora.

El tránsito entre revista de cine y revista femenina se materializó en Ecran en la coexistencia de la cobertura de la vida social, propio de las revistas magazinescas, junto a las noticias de las estrellas. Este formato, más allá de su estrategia comercial en el sentido de atraer a las lectoras y hacerlas participar de la revista, también hizo patente la tensión en las transformaciones de popularidad pública. La sociedad chilena comenzó a ver cómo la forma de notoriedad social basado en la riqueza y el apellido (Vicuña; Salazar) se le sumaba un modelo de celebridad basado en la fama

4 No obstante, en algunos casos la temprana curiosidad de los espectadores dio paso a la decepción de tener que escuchar diálogos y cantos en inglés; es más, "algunos sintieron que se trataba de un proceso violento: se estaba obligando a aprender o internalizar un idioma desconocido” (Iturriaga 258).

5 Tal como plantea Jorge Iturriaga, para 1930 las salas de exhibición sufrieron una jerarquización territorial con una revitalización en el centro. "Si en 1913 la oferta cinematográfica parecía extenderse por la ciudad como si de panaderías se tratara, en 1926 los datos dibujan una actividad más especializada, para la cual había que ir al centro" (231). A esto se sumó la construcción de salas grandes y confortables, con lo que mutó el tipo de consumo y el entorno social asociado al cine, anteriormente vinculado al conventillo y al barrio (232).

6 Utilizamos este doble juego de posiciones porque asumimos que los lectores de Ecran complementaron la asistencia al cine con la lectura de la revista y viceversa.

7 Estos contenidos abarcan: relaciones familiares, afectos y sentimientos, asuntos relacionados con el hogar, cuidado personal, aspectos prácticos de la vida doméstica y cotidiana, y cultura y entretenimiento como apuntes de literatura, arte y cine (Méndez 293-4). 
y el espectáculo, propio de la cultura de masas. Esta nueva noción de celebridad vino aparejada con la irrupción de figuras como el artista, la estrella y el ídolo deportivo. Estas "figuras" nacionales e internacionales se proyectaron socialmente como "talentos, arquetipos, habilidades, ejemplos, poses, fotogenies" (Ossandón, "Los mudos rostros" 127). Diferenciándose de las figuras públicas del siglo XIX, como el publicista, el político, el intelectual, las saloniéres y las filántropas "señoras de familia".

Con su despliegue de imágenes y con un énfasis no en la información u opinión, sino en la aparición y en la apariencia, revistas como Ecran afianzaron la modernización de los formatos y códigos de expresión y difusión escrita. Esto en sintonía con el escenario social donde el conocimiento del "otro" se redujo a la formación de juicios en virtud de la impresión que causaba su aspecto externo (Dussaillant 198). Esto se vio reflejado en la importancia que tomó la fotografía, por ejemplo, en la sección de notas sociales de las revistas. Asimismo, esta modernización de la prensa abarcó la materialidad de la revista (tipo de papel, cantidad de imágenes, diagramación) como elemento central para atraer lectores. Al mismo tiempo, en la relación entre productor/ receptor se priorizó el binomio mostrar/mirar, y tomó un rol secundario el binomio decir/lectura (63). Así, las lectoras y lectores realizaron el ejercicio de (h)ojear las imágenes y leer lo que intencionalmente se seleccionaba (Ossandón, "Zig-Zag” 65).

En Ecran el uso de las fotografías buscó potencia una cultura del mirar que tuvo como elementos principales el disfrute y la divulgación, donde las imágenes de las estrellas adquirieron la condición de una atractiva espectacularidad visual del glamour. Esto no fue casual, pues las imágenes promocionales producidas por el sistema del estrellato fueron diseñadas para que "se hablara no de la estrella como persona sino como imagen" (Reyes 75). Imágenes que incitaban a los espectadores a "mirar" los conceptos de éxitos, riqueza, amor y género que las estrellas proyectaron.

\section{El glamour hollywoodense y la moda en Ecran}

La noción de glamour ha estado estrechamente vinculada a las mujeres (Gundle), y especialmente al cine y sus estrellas (Barrientos; Ramos). De hecho, la palabra glamour fue reinventada por los departamentos de prensa y publicidad de Hollywood ${ }^{8}$. Para Gundle y Castelli, constituye un sistema de género construido como femenino, donde se distinguen cuatro tipos de mujeres que lo poseen: la cortesana, la corista, la mujer de alta sociedad y la estrella. En cambio, para Dyhouse el glamour es un tipo de encanto sofisticado femenino que surgió en las primeras décadas del siglo xx vinculado al consumo, la cultura de masas y la moda.

8 El origen está en un vocablo escocés para describir algo o alguien con encanto y carisma. A su vez, el uso de la "u" es intencional, para darle más glamour al término (Chocano). 
Desde su aparición, el glamour ha proyectado formas específicas en diversos contextos históricos y sociales. Así, en las décadas de 1920 y 1930 el estilo glamoroso fue personificado y practicado por las estrellas de Hollywood. Este dio como resultado la representación de una feminidad modernizada y moldeada en relación a expectativas y anhelos de sofisticación y lujo (Dyhouse 10). El uso de modas y maquillajes más atrevidos significó la oportunidad de adoptar una actitud alejada de la modestia, la sencillez y la delicadeza propia del discurso tradicional de la feminidad. Ello abrió el "camino para lograr una forma de identidad femenina más fuerte y vigorosa" vinculada al "deseo de lograr algo excepcional, una forma de aspiración, una ilusión de transformación femenina” (9). Sin embargo, esta transformación fue mayormente visual, reforzando las miradas hacia el cuerpo y resaltando, a la vez, el uso aristocratizante de dispositivos corporales como el vestuario, el peinado y el maquillaje.

La prerrogativa de la mirada mantuvo el control discursivo sobre el cuerpo y el vestuario de la mujer como objeto de deseo y de feminidad. Particularmente, porque "la indumentaria es uno de los ejemplos más inmediatos y eficaces del modo en que se les da género a los cuerpos, hombre o mujer, y cómo llegan a significar «masculinidad» $\mathrm{y}$ «feminidad»" (Entwistle 163). Más aun cuando históricamente la moda y la mujer se han convertido en una asociación indisoluble, como ya lo señalaba la aristócrata chilena Rosa Prat de Ortúzar en su manual La Mujer, su actuación en el Hogar de 1924: "La cuestión moda tiene importancia capital en la vida de la mujer. «Mujer y moda», son dos vocablos que no se pueden desunir. Aunque sea inteligentísima y de altos ideales, hablad de moda a una mujer y os responderá en seguida como un instrumento tocado en la parte más sensible" (355-6).

Tal como señala Pía Montalva ("La vida elegante"), la elección del vestuario y la cosmética dependen en buena parte de dónde, cómo y por qué se exponen los cuerpos investidos. En el caso de las estrellas, sus cuerpos son investidos con una función comercial y estética: deben ser bellos y seductores para convertirlos en deseables y envidiables. "En efecto, hay actrices que tienen tal originalidad y tal elegancia en el vestir que sus trajes sirven de modelos a miles y miles de personas en el mundo. Gloria Swanson, Lili Damita, Brigitte Helm, Greta Garbo, Lupe Vélez, son actrices elegantes que lanzan modas" ("Las estrellas del cine" 4).

Para las estrellas, la relación entre vestuario y glamour estuvo estrechamente ligada al gusto de ver y de ser mirado, "de exhibirse a la mirada de los demás" (Lipovetsky 41-2). De hecho, ellas fueron miradas en su "pura apariencia" y construidas como "sujetos de una moda" (Traversa 236). No obstante, cuando hablamos de moda, esta no solo abarca los elementos estéticos del vestuario, sino un sistema más amplio basado en la inconsistencia en materia de ornamentaciones, producto de la renovación de las formas con un valor mundano (Lipovetsky 23). Es decir, la moda incorpora en su movimiento un importante rasgo de novedad, y el vestido materializa ese gesto (Montalva, Morir un poco). En tal sentido, la estrella glamourosa como sujeto de una 
moda se transformó en ícono de estilo por su apariencia y elegancia en el vestir, pero también por sus gestos y desplazamientos.

De igual modo, el vestuario ha ido "sujetando los cuerpos de las mujeres a un mayor escrutinio que los de los hombres" (Entwistle 30). Este escrutinio ha estado unido a la concepción de belleza establecida en cada época (Eco), la que ha tenido como objetivo principal "lograr hacer a las mujeres más agradables a la vista de los hombres" (Benítez). Además, la definición de la belleza femenina ha sido construida históricamente desde la masculinidad a través del mecanismo mirada-poder. En el caso de las estrellas, estas fueron expuestas para ser percibidas por la mirada masculina o habitada por las categorías masculinas de los espectadores (Mulvey). En Ecran, estas categorías masculinas dispusieron al lector/espectador en una posición de poder, convirtiendo a las estrellas en objetos de deseo a partir de una belleza glamorosa para elogiar (Cánovas).

Si bien Hollywood y sus estrellas se instalaron como el principal referente de las nuevas tendencias en moda, los diseños seguían viniendo de París. Diseñadores como Madeline Vionnet, Paul Poiret, Jean Patou, Elsa Schiaparelli y Lanvin predominaban en el gusto e interés de las estrellas (Ramos 160). Por ejemplo, la estrella Pearl White viajaba especialmente a París a comprar los modelos que lucía en pantalla (158). La consigna que se instituyó fue: en París se diseña, pero en Hollywood se luce. Hay que mencionar también que la moda estuvo fuertemente influenciada por el estilo art decó. Los vestidos de las estrellas adoptaron los cortes geométricos y las líneas simples, en composiciones que favorecieron los conceptos de novedad y exclusividad.

EL sistema del estrellato no tardó en producir estrellas arquetípicas (Gubern 137), las que estuvieron estrechamente vinculadas al vestuario y a la actitud más o menos libertaria de sus inspiradoras. Así, las flappers popularizaron el pecho plano y las caderas estrechas, la cabellera corta y el maquillaje marcado (reservado hasta entonces solo a la prostituta), junto al uso de vestidos con cintura baja para mayor libertad de movimiento (Ramos 161). Esta idea de libertad también implicó la trasgresión de la vida amorosa, que entrelazó el escándalo con la pasión. La chica buena o "the american sweetheart", encarnada en Mary Pickford, tuvo como prototipo los vestidos en tonos pasteles, de una apariencia más conservadora e inocente. La vampiresa ofemme fatale, encarnada en Marlene Dietrich, Greta Garbo y Gloria Swanson, estableció un tipo de indumentaria sugerente: maquillaje muy marcado, vestidos ceñidos, con estratégicas aberturas y escotes en telas caras, decorados con los materiales más lujosos (163). En Ecran se dio espacio para mostrar los diversos estilos arquetípicos de las estrellas. En las figuras 1, 2 y 3 se pueden observar los modelos de moda en Hollywood: trajes ceñidos en línea recta y de largo mediano para siluetas de pechos planos y cinturas estrechas. En la figura 4, observamos las creaciones más audaces: traje de lana de oro, con escotes en espalda en forma de $\mathrm{V}$ simulados con crepe georgette, dejando al descubierto y en forma sensual la espalda. 


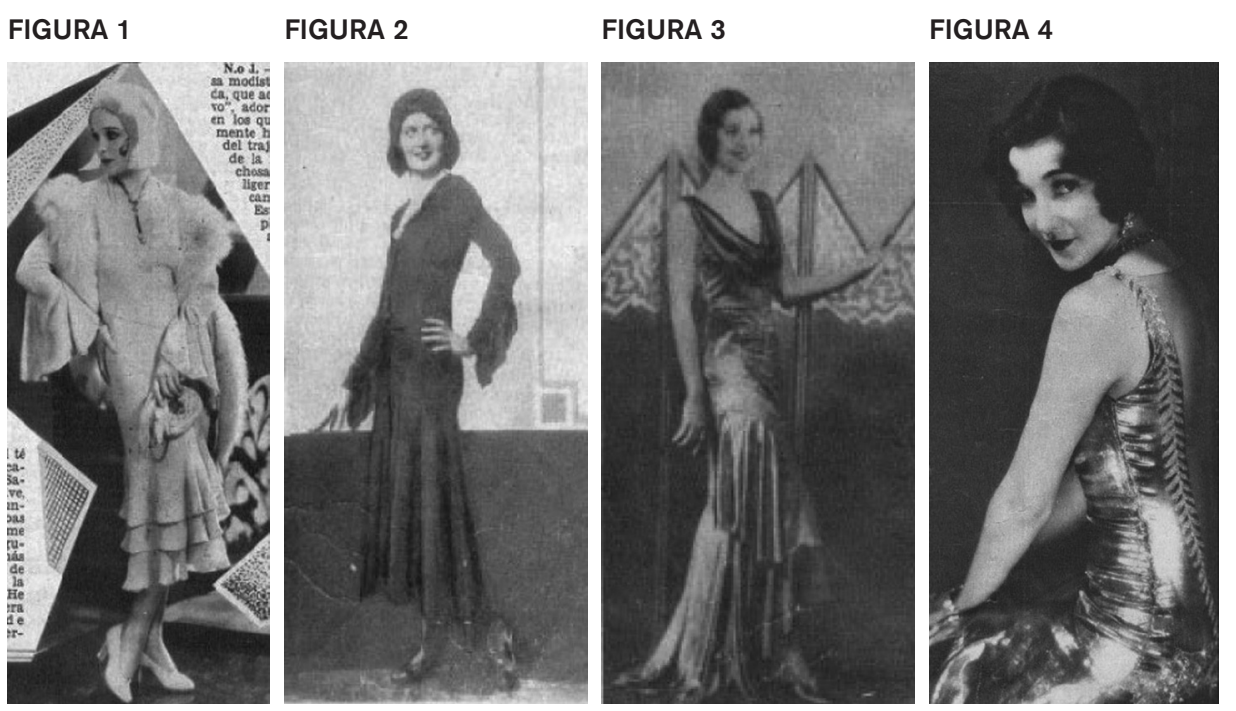

Figura 1. Traje de calle de líneas rectas, publicado en la sección “La moda en Hollywood”, en Ecran 4 (20 mayo 1930): 19. Figura 2. La actriz Merna Kennedy usando un sencillo y lujoso traje de tarde. Publicado en "Lo que gasta en vestir una estrella de Hollywood", en Ecran 11 (26 agosto 1930): 26. Fuente: www.memoriachilena.cl. Figura 3. La actriz Loretta Young en traje de líneas rectas. Publicado en "La belleza y la elegancia de Loretta Young", en Ecran 12 (9 septiembre 1930): 27. Figura 4. La actriz Milton Sillis en traje ajustado, publicado en la sección "La moda en Hollywood", en Ecran 7 (1 julio 1930): 19. Fuente: www.memoriachilena.cl.

La osadía de las flappers no dejó indiferente a las jóvenes de clase alta. En la novela chilena La Chica del Crillón, ambientada en la década de 1930, la joven aristócrata Teresa Iturrigorriaga relata los intentos de la juventud por imitar el vestuario y las actitudes de las estrellas norteamericanas: "nosotras -chiquillas con gusto a lecheestamos felices de hacer la parodia de las flappers, de ahorrar la plata de la ropa blanca para tomar cocktails de pisco, para marearnos con cigarrillos malos" (Edwards 27).

Poseer y vestir el vestido de moda fue un elemento central de la estética de la elegancia aristocrática. Por ello, adquirir el más costoso y, sobre todo, exhibirlo, fue para las mujeres de clase alta uno de los imperativos para destacar en la vida social. En este sentido, ellas replicaron de las estrellas el imperativo de sentirse admiradas, pero especialmente el de despertar entre las mujeres el deseo de imitar la capacidad de proyectar y vivir la elegancia.

\section{La representación del cuerpo femenino y su cuidado}

Para el sistema del estrellato, el cuerpo de la estrella asumió un valor de mercancía, pues "no hay ni un solo centímetro de su cuerpo, ni una fibra de su alma, ni un recuerdo de su vida que no pueda ser lanzado al mercado" (Morin 35). Esta mirada capitalista de los cuerpos de las estrellas tuvo como objetivo que la carga estética 
de la feminidad glamorosa provocara identificaciones masivas. Así, por ejemplo, la tendencia a un mayor cuidado del rostro se vio fomentada por el uso de la técnica cinematográfica del primer plano. Esta técnica permitió que durante la proyección de las películas se lograra una mayor cercanía del espectador con las estrellas, reforzando la conexión emotiva (Guerin 139). Esto impulsó el mercado de la belleza con el desarrollo de técnicas y productos para el cuidado facial. Así, los cosméticos como lápiz labial y máscara de pestaña se comenzaron a imponer como objetos básicos de consumo entre las mujeres, para destacar la apariencia y corregir los rasgos. Importantes maquilladores de las estrellas levantaron empresas comerciales que hasta hoy llevan su nombre: Max Factor, Elizabeth Arden y Helena Rubinstein (Dyhouse 55). La asimilación de la necesidad de dedicarle un mayor cuidado al rostro fue fomentada por la revista Ecran. Las lectoras encontraban en sus páginas declaraciones como la siguiente: "En el mundo entero existe el culto por la cara bonita, pero en Hollywood este culto es más completo y más razonable: hay que tener bonita la cara y perfecto el cuerpo" ("La esbeltez" 24).

Por otra parte, históricamente, la modificación de la concepción de belleza ha ido aparejada de cambios en los gustos sobre las proporciones corporales y/o el énfasis en un rasgo del cuerpo por sobre otro (Eco). De esta manera, el cuerpo y la belleza, en tanto construidos y normalizados cultural e históricamente, tomaron matices más exigentes en la figura de la estrella. El cuerpo delgado se impuso como un parámetro estético y de buena salud, rechazando los cuerpos abultados y rollizos entre las mujeres. Ecran hizo eco de esta tendencia comentando a sus lectoras que: "Para una estrella en su apogeo, la balanza es un árbitro de su bienestar y de su tranquilidad. Un kilo más o un kilo menos, es decisivo en las perspectivas de un artista de cine" (C. F. B. 17). En este sentido, la capacidad de la estrella de influenciar en la percepción de sus seguidoras terminó impulsando la delgadez como una norma social. La repercusión de esta construcción discursiva del cuerpo la podemos observar hasta el día de hoy en las expectativas mediatizadas que las mujeres se sienten obligadas a cumplir respecto de su imagen, que las lleva a intervenir su cuerpo de forma muchas veces no saludable (Moreno).

Para alcanzar el cuerpo delgado, este debía ser moldeado a través del ejercicio, la vida sana y, especialmente, el deporte. El secreto de "la belleza escultural de los cuerpos de las actrices de Hollywood", comentan en Ecran, "es muy simple, y está al alcance de todas: ejercicio y más ejercicio, metódico, desde la infancia, de modo que el cuerpo se acostumbre y necesite de él, exigiéndolo" ("Los deportes y las estrellas" 17). El movimiento se instala como una premisa que modifica el cuerpo, socializando la práctica de la gimnasia (Traversa 242). Sin embargo, el deporte, a diferencia del ejercicio, fue socialmente asumido con connotaciones negativas para el cuerpo femenino, acusando que su práctica significaba la pérdida de la feminidad por parte de las mujeres. Para mermar tal prejuicio, la revista utilizó el ejemplo de las estrellas para reivindicar dicha práctica: 


\begin{abstract}
Existe aún entre nosotros el error de creer de que la mujer entregada a los deportes pierde su femineidad y conviértese en una especie de atleta nervudo que horroriza a los hombres. Nada de eso. ¿Quiénes poseen en el mundo entero mayor prestigio por su feminidad, su belleza y su gracia que las estrellas cinescas de Hollywood? Y sin embargo, ninguna de ellas dejaría de hacer ejercicios y vida deportiva ordenada, asegurando la mayoría de que deben a ello la perfección de sus figuras ("La esbeltez" 24).
\end{abstract}

El miedo a la pérdida de la feminidad ha sido uno de los elementos discursivos con que ha operado la normalización de los cuerpos de las mujeres. El alejamiento de las formas femeninas implicaba para las mujeres ser asociadas con la ridiculez y la fealdad, mientras que aquellas que gozaban de una apariencia acreditada fueron relacionadas con la elegancia y la belleza. El temor a perder la "esencia" femenina fue un importante elemento a considerar al momento de evaluar nuevas modas corporales, pues el poder de las normativas del género impidió una ruptura con los cánones llamados femeninos y más bien se buscó la vía de la negociación para mantener una continuidad (Kaczan 153). Así por ejemplo, en Ecran no se condenó la práctica de la gimnasia, pero sí se condenó la actividad repetitiva y excesiva del ejercicio gimnástico como antifemenino, pues este exceso solo lograría "producir deformaciones atléticas" transformando a una muchacha cualquiera en un sujeto "tan fuerte como feo" ("La esbeltez" 24).

La revista desplegó esta nueva normatividad del cuerpo no solo a través de las imágenes de las estrellas, sino también en la publicidad. Esta promocionaba, por ejemplo, el consumo de tabletas laxantes para adelgazar, tal como se ilustra en la figura 5. En la imagen, se observa una mujer delgada que se acerca en una actitud de confidencia a una mujer rolliza para comunicarle el secreto de su delgadez. Así, el eslogan publicitario apela a la idea de una intervención farmacéutica que permitiría eficazmente cumplir con la esbeltez como estándar de belleza. Esto porque el cuerpo con sobrepeso fue rechazado constantemente como una silueta carente de elegancia. Por su parte, en la figura 6 se destacan las propiedades de las fajas para darle la forma recta a la silueta. Aquí la imagen invoca los recursos diseñados para corregir y amoldar el cuerpo con el fin de acomodarse a los nuevos diseños y patrones. En un intento de acercarse al ideal del cuerpo de las estrellas, la ropa interior de las mujeres fue acondicionada por los diseñadores: "Para parecerse a las vampiresas del cine americano, envueltas en zorros plateados, las mujeres adoptarán la faja elástica, que reduce el contorno de las caderas, y el sujetador, que deriva de la «modestia» de sus madres" (Vaquero 128).

El tamaño del busto también fue interpelado por la nueva forma de la silueta femenina. El uso acostumbrado del corsé que buscaba ajustar exagerada y artificialmente el torso femenino dando la forma de una cintura de avispa que elevaba y abultaba el busto, dio paso a la silueta delgada de pechos pequeños. Esta disminución en la proporciones del busto comenzó a generalizarse cuando el modisto francés Paul Poiret popularizó el vestido sin corsé, "imponiendo otra línea que evitaba la yugulación de 
FIGURA 5

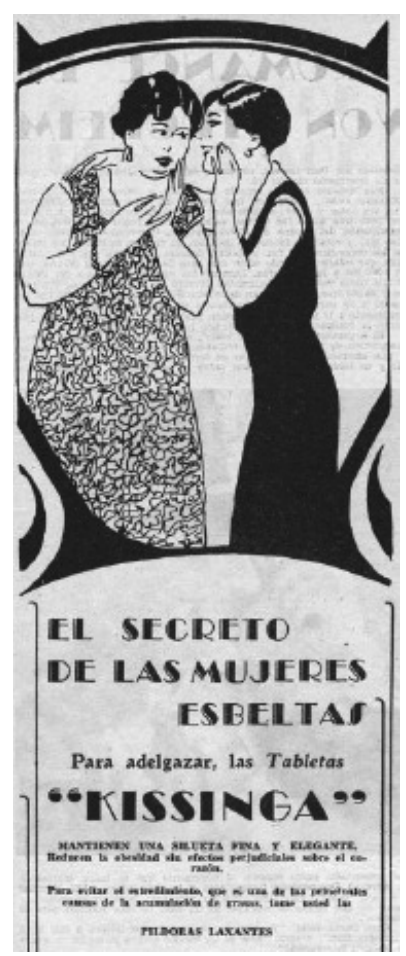

FIGURA 6

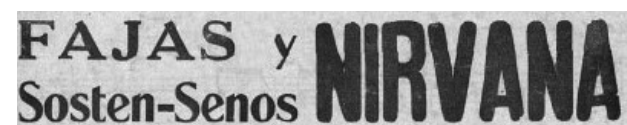

Nuevomodelo de FAJA NIRVANA 32 cona la eintura un poco mat mar-

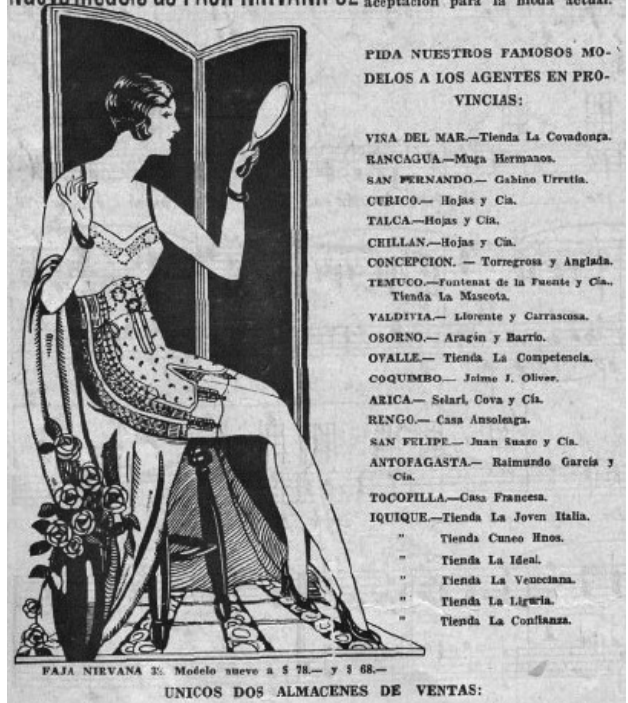

Ahumada, 55
Ahumada, 323

Figura 5. Publicidad de tabletas para adelgazar publicada, en Ecran 19 (16 diciembre 1930): 12. Figura 6. Publicidad de fajas y sostenes Nirvana, en Ecran 8 (1 julio 1930): 44. Fuente: www.memoriachilena.cl

la cintura abdominal" (Traversa 238). La ausencia de corsé buscó resaltar las curvas naturales del cuerpo femenino junto con dotarlo de mayor movilidad y comodidad. Esta fractura con el "talle de avispa" y toda una tradición de los grandes modelos vestimentarios "fue precedida de un conjunto de intervenciones desde el campo de la patología y la higienística médica acerca de los males del constrictor corsé" (238).

Las piernas, junto con el rostro y la silueta, fueron también relevadas a un sitial de feminidad y poder. La individualización y fragmentación de las piernas, instalada tras la Primera Guerra Mundial, derivó en su exaltación como objeto erótico para la satisfacción de la mirada masculina. Así lo leemos en Ecran:

Las piernas han invadido todos los aspectos de la vida, con su poder seductor. Han dado fuerzas nuevas al arte, al teatro, al comercio y la industria han llenado de perspectiva nuevas el cinematógrafo. Además han sido motivo de triunfo fácil para muchas mujeres y el origen de pasiones volcánicas en el corazón de muchos hombres... ¿Qué importa que una niña no tenga el rostro perfecto si lleva unas pantorrillas deliciosas, unas medias que abrazan una flor de perfección? Ellas le abrirán todas las puertas, siempre que tenga el valor para demostrar ese tesoro sin precio (R. C. 9). 
FIGURA 7

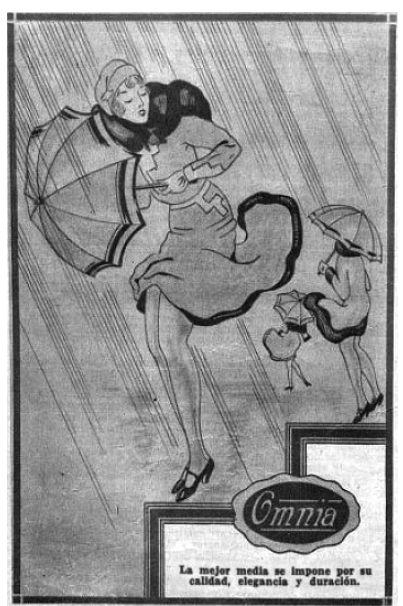

FIGURA 8

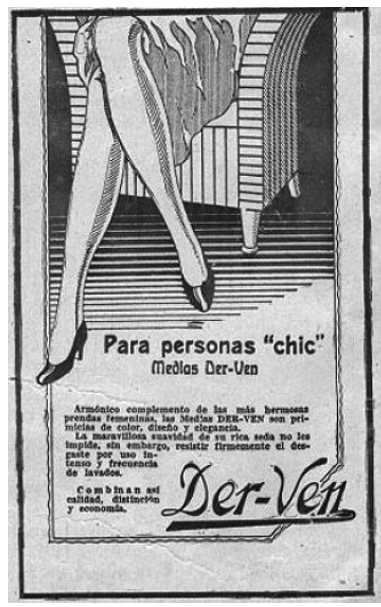

FIGURA 9

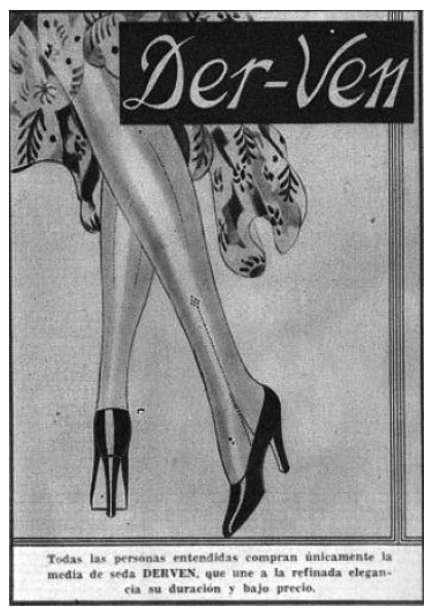

Figura 7. Publicidad de las medias Omnia, en Ecran 9 (29 julio 1930): 39. Figura 8, Publicidad de las medias DerVen, en Ecran 10 (12 agosto 1930): 7. Figura 9. Publicidad de las medias Der-Ven, en Ecran 18 (2 diciembre 1930): 6. Fuente: www.memoriachilena.cl

Entre los múltiples comentarios que la revista señaló respecto de la apariencia femenina, la seducción de las piernas se impuso incluso a la belleza del rostro. Esto porque, para Ecran: "Los hombres miran a las mujeres por sus piernas y siempre las valorizan de abajo hacia arriba" (R. C. 9). Esta sobrevaloración de las piernas reforzó la dominación masculina sobre el cuerpo de las mujeres, aprisionándolas más aun a la mirada y expectativa de los hombres (Bourdieu). Expectativa que además demandó que las piernas fueran vestidas y exhibidas de una manera sensual y provocativa, como lo hacían las estrellas del cine. Para Enrique Gil, vestir las piernas con medias trasparentes fue un signo de distinción femenina, pero también constituyó una ícono del deseo fetichista que representó (y aún representa) el tributo imaginario que deben pagar las mujeres para poder acceder al mercado público de las relaciones sociales (18). En Ecran, las piernas vestidas con medias comenzaron a aparecer poco a poco entre las imágenes de las estrellas, pero fueron más evidentes en la publicidad, que las asoció a un estilo "chic" y elegante. Así, se observa en las figuras 7, 8 y 9 cómo la publicidad de las medias resaltó cada vez más la imagen de piernas delgadas y de líneas estilizadas. A su vez, en las figuras 8 y 9 se hace evidente la fragmentación de la representación de las piernas hecha por la publicidad, expresada gráficamente con el uso de los primeros planos del anuncio.

La relevancia social que alcanzó el uso de las medias entre las mujeres chilenas se puede apreciar en los comentarios de la protagonista de la novela La chica del Crillón: la joven Teresa estaba dispuesta a pagar un alto precio por ellas, incluso cuando adquirirlas significa gastar el dinero con el que "podría vivir un mes cualquier familia de clase pobre" (Edwards 98). 
Igualmente, las estrellas se lucieron en traje de baño encarnando un progresivo destape del cuerpo femenino y su desnudez, asociada a la nueva costumbre de de visitar las playas para tomar baños de sol. De hecho, el uso del traje de baño que progresivamente dejó brazos y piernas al descubierto vino a cubrir las aspiraciones de una estética renovada donde el tono tostado funcionaba como signo de distinción (Kaczan).La sociedad chilena paulatinamente comenzó a escapar del ajetreo capitalino para "veranear" en la playa (en vez de trasladarse al fundo) y descansar, imitando la idiosincrática europea (Góngora 308). Viña del Mar fue el balneario preferido para estos descansos; de hecho, la estancia allí "permitía alimentar expectativas y alcanzar mejor estatus social, que colaboró fuertemente a consolidar la asociación de esta ciudad con un vivir aristocrático, identificado abiertamente con las características de la belle époque" (Salomó 78). La playa se convirtió en un paraíso para la recreación y el paseo de los santiaguinos, donde la introducción de la práctica de tomar sol y disfrutar del agua fue imponiendo el uso del bañador (Góngora 321). Así, se pasó del antiguo traje de capas de géneros pesados y rígidos a uno de telas más livianas y ceñidas al cuerpo, que mostraba la totalidad de los brazos y las piernas hasta medio muslo (Kaczan 148). Para 1931, la publicidad de las revistas difundía modelos de trajes de baños femeninos más ceñidos y sofisticados, como los usados por las estrellas:

\footnotetext{
Ahora llegó el traje de baño que usa el mundo elegante en Viña del Mar, Biarritz, Deauville... Elegante, moderno en los colores, estilizados en las líneas, cuidadosamente confeccionado para favorecer su porte, el Jantzen es el traje que usted justamente necesita. Perfectamente ajustado al cuerpo, hecho de pura lana, tejido con el famoso punto de malla Jantzen y coloreado con tonos firmes; estos trajes constituyen lo que las personas más distinguidas de nuestra sociedad estaban buscando (cit. en Salomó 35).
}

Sin embargo, las imágenes de estrellas en trajes de baño no fueron numerosas en Ecran. Difícil sería esbozar una explicación para esta ausencia, pero podemos especular que el traje de baño al estilo Hollywood era aún muy atrevido para la sociedad chilena, como se detalla en las figuras 10 y 11 . También pudo haber afectado que el uso del bañador todavía no era una moda masificada.

\section{El glamour hollywoodense y las mujeres chilenas}

El brillo, la moda y el desenvolvimiento femenino asociado al cine hollywoodense cautivaron a las jóvenes de clase alta y las predispuso a una norteamericanización de sus gustos y de consumo. El cambio de referencia implicó desplazar su imitativa mirada desde el estilo de vida identificado como belle époque al de la american way of life, lo que produjo una paradoja de continuidades y resistencias para la construcción identitaria de la clase alta. 
FIGURA 10

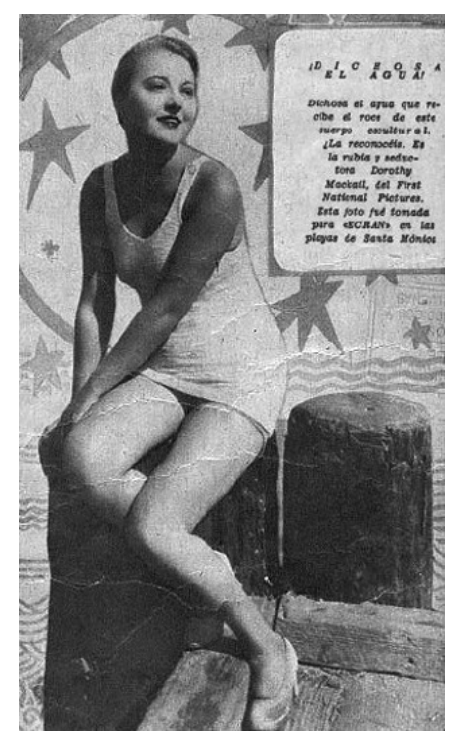

FIGURA 11

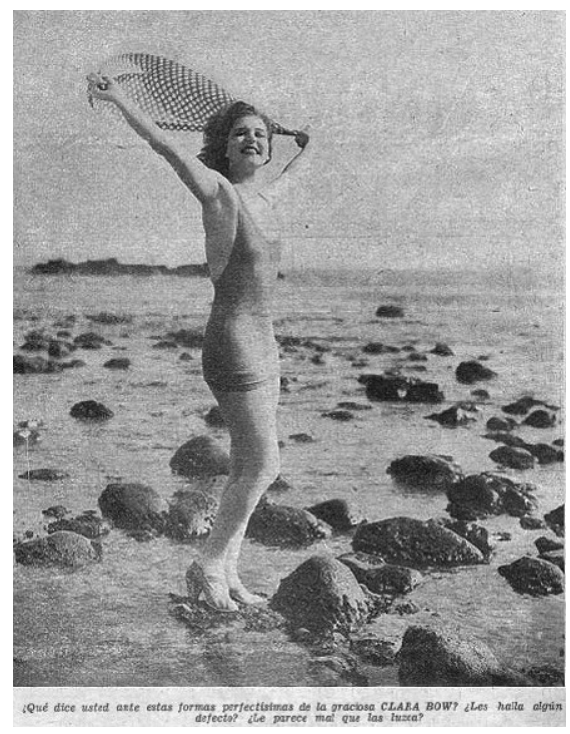

Figura 10. La actriz Dorothy Mackail con su "cuerpo escultural" posa en las playas de Santa Mónica, en Ecran 2 (22 abril 1930): 26. Figura 11. La actriz Clara Bow posando en traje de baño, en Ecran 7 (1 julio 1930): 9. Fuente: www. memoriachilena.cl

Durante la belle époque, la clase alta chilena construyó una identidad oligárquica diferenciándose de la clase media y el proletariado. Para ello, tanto hombres como mujeres se hicieron proclives a adoptar nuevas costumbres, patrones de consumo foráneos, al adquirir gustos e intereses que se presentaron como novedosos y modernos (Vicuña). En este escenario social, exhibir el "buen tono", es decir, "todo aquello que es tenido por elegante y refinado" (Barros y Vergara 57-8), se convirtió en un elemento esencial de identidad de clase. La demostración de las destrezas de ese refinamiento fue manifestado en la ajetreada vida social de las mujeres, pues ellas "no sólo salen de sus casa para asistir a misa, sino que además hacen y devuelven visitas, van al teatro o a comprar y participan en distintos paseos por la ciudad" (Dussaillant 196-7). Esto las hizo asiduas consumidoras con el fin de mantener la apariencia de elegancia en todos los actos de sociabilidad. Importantes aliados para el desempeño de esta actuación de la elegancia fueron la prensa y las revistas, donde la cultura del mirar encontró una audiencia: "Bajo el título de «notas sociales» aparecen los elegantes llegando de Europa, bailando en una fiesta o haciendo visitas de caridad" (Dussaillant 199).

En cambio, el giro hacia el estilo de vida norteamericano como referente incluyó nuevos estándares corporales y de consumo que fueron encarnados, como ya lo hemos señalado, en el estilo glamoroso de la estrella hollywoodense. Para las mujeres de clase alta, especialmente las jóvenes, la estrella glamorosa supuso una representación de cómo ser una mujer moderna y cautivante. Sin embargo, las madres no estaban dispuestas a 
permitir que sus hijas adoptaran indistintamente el estilo glamoroso hollywoodense sin antes adecuarlo a las convenciones sociales y morales de su clase, especialmente para mantener el aura aristocratizante de la pertenencia social. Esto ante la evidencia de que la mayoría de las estrellas no tuvieron un origen aristocrático, sino que más bien procedían de estratos sociales humildes, y fueron los estudios cinematográficos quienes se encargaron de prepararlas para que adoptaran la pose y los gustos refinados que reproducían tanto dentro como fuera de la pantalla (Ramos 164).

Ante la representación del estilo glamoroso hollywoodense, las jóvenes de clase alta se sintieron particularmente atraídas por la moda del flapperismo, que supuso una rebelión contra la delicadeza de la noción de feminidad. Esto porque el uso de melenas cortas, transparencias, lápiz labial, consumo de cigarrillos, desenvoltura y alardes de audacia fueron interpretados como una masculinización de la apariencia de la mujer. En la década de 1920, los grupos conservadores chilenos criticaron fuertemente el estereotipo de las flapper, a quienes consideraban peligrosamente rupturistas con el "debe ser" de una mujer decente y elegante, y temieron que se generalizara en la juventud chilena (Montalva, "La vida elegante" 179). Sin embargo, estas nuevas tendencias de feminidad solo fueron adoptadas por algunas jóvenes que tuvieron la osadía de relevarse ante los cánones conservadores. Para 1930, la adopción de modas foráneas y atrevidas se fue flexibilizando y masificando. "Por esta fecha adoptan las sinuosidades provocativas de los nuevos estilos desde las más remilgadas hasta la mujer del pueblo; estas últimas han abandonado gradualmente sus mantos y largas vestiduras. Todas las jóvenes, casi sin excepción, demuestran un marcado interés en conocer todas las posibles innovaciones" (Cohen 139). La estrategia para esta flexibilización fue presentar el cuerpo femenino en el filo de lo apropiado e inapropiado, potenciando una feminidad flexible como reflejo de los valores modernos cambiantes.

Ecran visibilizó la apropiación que hicieron las lectoras del glamour de Hollywood. En la misma revista podemos observar cómo la imagen de la estrella glamorosa y los retratos de jóvenes que buscaban imitar ese estilo femenino moderno. En la sección "Bellezas chilenas" y "Comentario social" de la revista, se podían observar los retratos de estas jóvenes recreando las poses y los gestos plasmados en las fotografías de las estrellas hollywoodenses. Así, mientras en una página aparecía Greta Garbo, Norma Shearer o Marlene Dietrich, en la siguiente página era menester encontrar las fotografías de las jóvenes de la clase alta chilena imitando sus estilos glamorosos.

Tradicionalmente, la distinción y la elegancia aristocráticas se trasmitieron preferentemente en términos de la pose (Traversa 241). Los retratos y fotografías se transformaron en el mecanismo para trascender la representación del estatus social, como en su momento lo fueron las pinturas. Durante el siglo xx y comienzos del $\mathrm{xx}$, las fotografías se caracterizaron por retratar cuerpos rígidos, "en los que la protagonista se apoyaba en una columna o mueble, o estaban sentada y mirando 
FIGURA 12

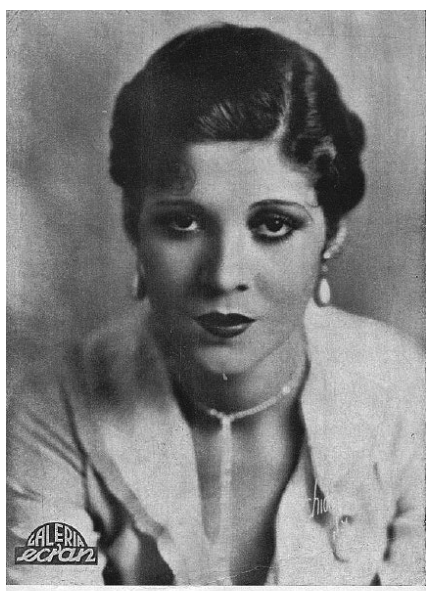

OLVE BORDEN
FIGURA 13

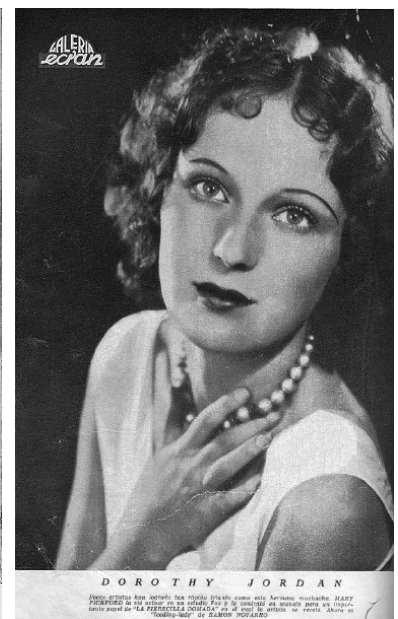

FIGURA 14

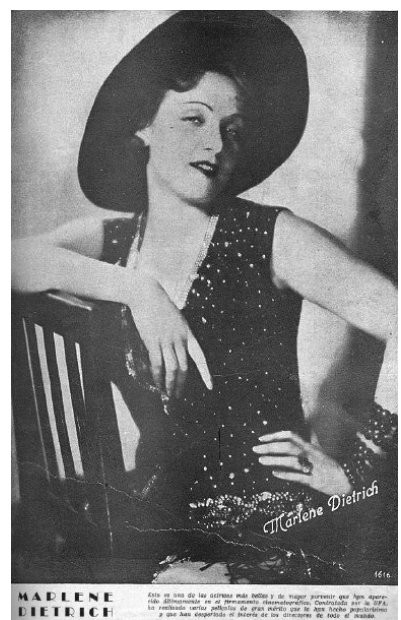

Figura 12. Retrato de la actriz Olive Borden "Galería de Ecran", en Ecran 8 (15 julio 1930): 22. Figura 13. Retrato de la actriz Dorothy Jordan en "Galería de Ecran", en Ecran 11 (26 agosto 1930): 24. Figura 14. La actriz Marlene Dietrich, en Ecran 4 (20 mayo 1930): 19. Fuente: www.memoriachilena.cl

el infinito" (Retratos de mujer 27). La influencia de Hollywood renovó ese espíritu fotogénico de la aristocracia con nuevos modos de posar. Así, la pose rígida dio paso a la apropiación de la cualidad del "it" de las estrellas. Es decir, el magnetismo de la imagen de la estrella que involucraba el juego entre la sensualidad y la inocencia. El uso de esta capacidad de atracción de las imágenes se conoció como fotogenia, definida como una especificidad cinematográfica de las poses y gestos de las estrellas (Vigarello 216).

En Ecran se puede observar como la posición corporal, los gestos y la dirección de la mirada de las jóvenes fueron tomando mayor importancia en la composición fotográfica. Para ello, fue necesario recurrir a un buen fotógrafo, elegir los ángulos y cuidar la luminosidad. Por ejemplo, si en las fotografías de las estrellas invocaron una belleza fotogénica acompañada de ademanes delicados y de una mirada directa, que motivaba un enfoque en la expresión de los ojos (figs. 12, 13 y 14), las fotografías de las jóvenes chilenas de la alta sociedad también apelaron a estos gestos: resaltando cada vez más una diversidad de emociones en sus rostros, al jugar con la mirada y sonrisa (figs.15, 16 y 17).

En las fotografías de las estrellas (figs. 13y 14), se puede apreciar algunos componentes de la pose que fueron imitados en los retratos de las jóvenes de clase alta chilenas: por ejemplo, la postura del cuello, que lo hace verse delgado y alargado y que entrega sofisticación a la apariencia (figs. 15 y 17), así como la posición de las manos, que le dotan de movimiento al encuadre de la fotografía (figs. 15 y 16). La teatralidad de la pose adquirió una mayor preponderancia, y se observaron poses dinámicas y expresivas (fig. 17); posiciones casuales, como sentada en el suelo al 
FIGURA 15

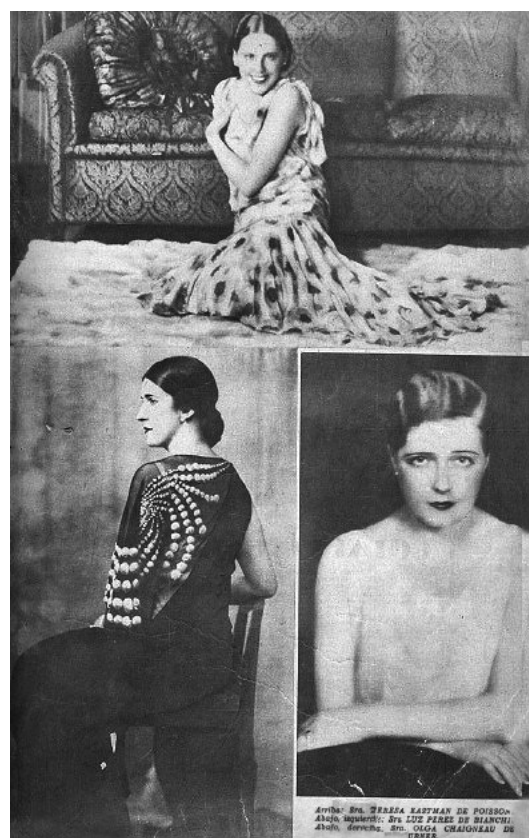

FIGURA 16

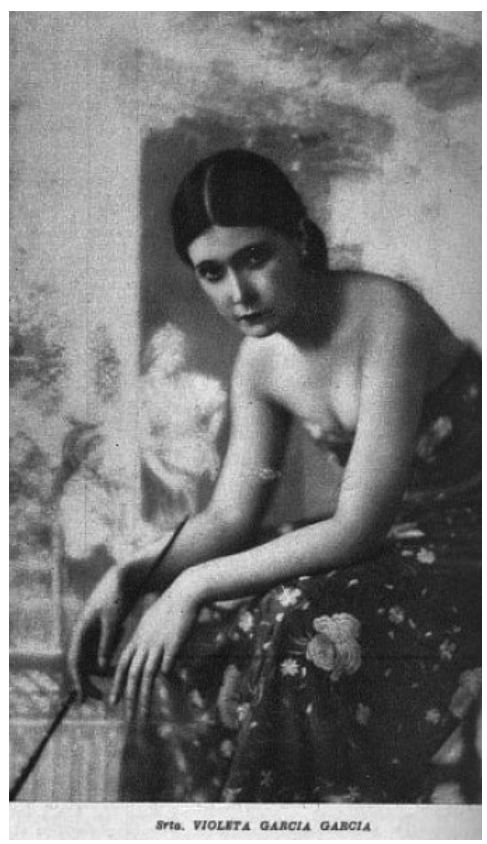

STE. VIOLTTA GARCIA GAMCIA

Figura 15. Fotografías de las señoras Teresa Eastman de Poison, Luz Pérez de Bianchi y Olga Chaigneau de Ubner publicados en la sección "Bellezas Chilenas", en Ecran 6 (17 junio 1930): 9. Figura 16. Fotografía de la Srta. Violeta García García publicada en la sección “Comentario social”, en Ecran 16 (4 noviembre 1930): 4. Fuente: www.memoriachilena.cl

\section{FIGURA 17}

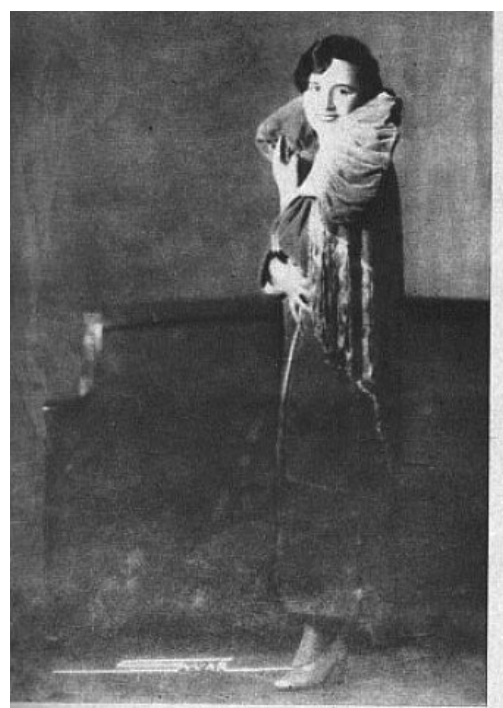

STE. RAQURL ERRROS LARAAIN

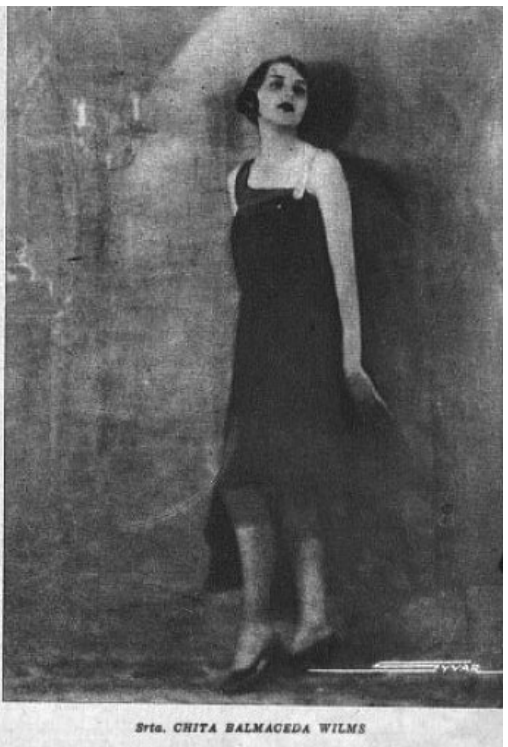

STta. CMITA BALACEDA WILNS

Figura 17. Fotografías de las señoritas Raquel Barros Larraín y Chita Balmaceda Wilms, en sección "Bellezas Chilenas", en Ecran 8 (15 julio 1930): 5. Fuente: www.memoriachilena.cl 
frente de un sillón, con brazos apoyados en las piernas mientras se sostiene una boquilla (fig. 15); o sentada en una silla de perfil, donde la línea estilizada de la espalda toma protagonismo (fig. 15). En cuanto a la moda, las fotografías muestran el uso de pieles y vestidos que dejaban al descubierto los hombros (fig. 17). Este nuevo código perceptivo de poses casuales, dinámicas e sugerentes en las jóvenes de la clase alta funcionó como una proyección visual del glamour hollywoodenses.

En el caso de las mujeres de clase media, el paulatino ingreso a la esfera laboral incidió en su capacidad de consumir bienes y acceder a las tendencias de moda. En la medida en que sus ocupaciones laborales les imponían como obligación y requisito la "buena presencia", se posicionaron como eventuales consumidoras. De esta manera, actividades laborales como el desempeño de profesiones liberales (abogadas, dentistas, matronas, asistentes sociales, médicos, farmacéuticas, etc.) o de trabajos remunerados como los de empleada pública, de comercio, de oficina $y$, mayormente, de profesora (Salazar y Pinto 166), les permitió darse algunos pequeños lujos y gustos mediante la adquisición de medias, perfumes, sombreros, etc. Estas adquisiciones las hicieron pensando en mantener la coquetería y elegancia femenina en sus actividades laborales, especialmente cuando sus prácticas profesionales estaban asociadas a desempeños masculinos, situación que les imponía un cuestionamiento a su feminidad. Para estas mujeres, expresar su feminidad a través del arreglo personal significó una elección identitaria en su ingreso al espacio público, pero también lo hicieron para circular en el mercado de las relaciones sociales (especialmente el matrimonio). Para ello imitaron el glamour de las estrellas a través del uso de accesorios como sombreros, replicando el peinado de moda, uso de medias, y vestidos elegantes pero de telas sencillas.

En cambio, para las vendedoras y oficinistas (secretarias o mecanógrafas, por ejemplo), el requisito de la "buena presencia" demandó el uso uniforme de trabajo que incluía vestido o traje de dos piezas, uso de medias, zapatos de taco, maquillaje y peinado (Queirolo 40). Esto significó que debieron acomodarse ante la necesidad del acceso laboral a los estándares corporales y de belleza, y para ello trataron de articular la elegancia con la sencillez.

El acceso de la clase media con menores recursos al vestuario de moda se vio facilitado, por un lado, a través de los patrones y moldes de diseños de vestidos, trajes, blusas, etc., que fueron publicados en las revistas femeninas. Estas secciones apelaban a los conocimientos y habilidades propios de la vida doméstica femenina, especialmente a los de costura. La misma Ecran, a fines de la década de 1930, incorporó en sus páginas patrones de trajes que acomodaron los estilos de acuerdo con la impronta de las estrellas.

No obstante, hay que señalar que la crisis económica de 1930 mantuvo a las mujeres de menores recursos más preocupadas de ayudar a sostener a sus familias que de obsesionarse con vestirse a la moda. 


\section{Conclusiones}

Sin duda, como señala Stefan Rinke (2002), el cine se transformó en las primeras décadas del siglo xx en el medio más importante de la formación de una cultura de masas en Chile. Las películas afectaron la vida diaria de la sociedad chilena, sobre todo mediante la divulgación de una maquinaria representacional de la modernidad al estilo norteamericano que tuvo como íconos visuales a las estrellas hollywoodense. Las imágenes y los innumerables artículos sobre las vidas y gustos de las estrellas que fueron publicados en la revista Ecran contribuyeron a la expansión de la industria y la formación de públicos atraídos por el brillo de Hollywood.

En la sociedad chilena, y especialmente en la clase alta, el estrellato fue percibido como una nueva forma de notoriedad y popularidad. La moda en el vestuario y las poses más sugerentes y casuales de las fotografías de las jóvenes publicadas en la revista Ecran nos refieren al poder que tuvieron las estrellas para imponer tendencias más allá de Estados Unidos. Pero, más aun, evidencian la disposición de la sociedad chilena de imitar y asimilar las tendencias venidas de Estados Unidos, las que fueron percibidas como una "mercancía irresistible" (Purcell "Una mercancía irresistible").

Las mujeres fueron el principal público de Ecran, revista que conjugó en sus páginas un periodismo de espectáculo y un formato de revista femenina. Esto la convirtió en una plataforma ideal para introducir una particular representación de feminidad que tuvo al glamour como su eje articulador. El estilo glamoroso de las estrellas en las páginas de la revista tomó la forma de nuevos parámetros corporales y de apariencia femeninos que se sistematizaron mediante la puesta en escena de una estética de la elegancia. La forma del cuerpo y el modo de vestirlo se constituyó como un "debe ser" vestimentario cuyo imperativo era "estar a la moda". En este sentido, Ecran no solo se instaló como un vaso comunicante entre el star system y el lector/espectador, sino que también fue una de las principales plataformas con que las estrellas transmitieron su poder cautivante de lo que debía ser una mujer modernamente elegante. Así, Ecran presentó y difundió el estilo glamoroso como una alternativa de encanto y sofisticación entre las mujeres chilenas de clase alta y media. A su vez, este estilo glamoroso sustentó un discurso disciplinante del cuerpo a través de la atracción del brillo del espectáculo de Hollywood, un brillo construido y artificial, en la medida en que las estrellas fueron fabricadas como mercancía.

La moda y las poses más sugerentes y casuales de las fotografías de las jóvenes publicadas en la revista Ecran nos refieren al poder que tuvieron las estrellas para imponer tendencias más allá de Estados Unidos. Pero, más aun, evidencian la disposición de la sociedad chilena de imitar y asimilar las tendencias venidas de Estados Unidos, las que fueron percibidas como una irresistible mercancía (Purcell, "Una mercancía irresistible"). 


\section{Referencias}

Barrientos, Mónica. "Comunicación y moda: la perspectiva cinematográfica contemporánea estadounidense y europea”. Caleidoscopio 28 (2013): 163-189. Impreso.

Barros, Luis y Vergara, Ximena. El modo de ser aristocrático: El caso de la oligarquía chilena hacia 1900. Santiago: Ediciones Aconcagua, 1978. Impreso.

"Bellezas Chilenas", Ecran 6 (17 junio 1930): 9. Impreso.

"Bellezas Chilenas", Ecran 8 (15 julio 1930): 5. Impreso.

Benavente, Carolina. Mujeres espectrales. Mujeres y espectáculos en Chile, 1920- 1973. Santiago: Centro cultural de España, 2009. Impreso.

Berman, Marshall, Todo lo sólido se desvanece en el aire. Madrid: Siglo XXI, 1998. Impreso.

Benítez, Bárbara. La noción de feminidad y belleza presente en los contenidos de la revista Cosmopolitan en sus ediciones de enero, febrero y marzo 2009. Tesis de Licenciatura en Sociología, Universidad Oriente, Venezuela, 2012. Impreso.

Bongers, Wolfgang. "El cine y su llegada a Chile: conceptos y discursos". Taller de Letras 46 (2010): 151-174. Impreso.

Bourdieu, Pierre. La dominación masculina. Madrid: Anagrama, 2003. Impreso.

C. F. B. "El cultivo de la forma en Hollywood". Ecran 20 (30 diciembre 1930): 17. Impreso.

Cánovas, María Carmen. "Mujeres (y) miradas: Arquetipos femeninos a través del star system. El adoctrinamiento social a través de las representaciones femeninas cinematográficas en la España de la postguerra”. Coord. Alberto González. No es país para jóvenes. España: Asociación Histórica Contemporánea/ Instituto Valentín Foronda, 2012. Impreso.

Chocano, Carina (2006). “The allure of Illusion”. Los Angeles Times (21 Mayo 2006). Web. 1 Sep. 2015.

Cohen, Cecilia. "Del talle de avispa al talle de avispa". 1905-1950, 50 años Medio Siglo de Zigzag. Número especial (1954): 134-142. Impreso.

"Comentario social". Ecran 16 (4 nov 1930): 4. Impreso.

Correa, Sofía, Consuelo Figueroa, Alfredo Jocelyn-Holt, Claudio Rolle y Manuel Vicuña. Historia del siglo xx chileno. Santiago: Sudamericana, 2001. Impreso.

Cuevas, Raúl. "El ensueño que nos trae el cine”. Ecran 13 (23 septiembre 1930): 28. Impreso.

Cumplido, María José. “American way of life. Cambios de las masculinidades en Chile a partir de la influencia norteamericana 1920-1935”. Punto de género 3 (2013): 9-25. Impreso.

de Lauretis, Teresa. “Tecnología del género". Diferentes etapas de un camino a través del feminismo, España: horas y Horas, 2000. 33-70. Impreso.

Dussaillant, Jacqueline. Las reinas de Estado. Consumo, grandes tiendas y mujeres en la modernización del comercio de Santiago (1880-1930). Santiago: Ediciones Universidad Católica de Chile, 2011. Impreso. 
Dyer, Richard. Las estrellas cinematográficas. Historia, ideología, estética. Buenos Aires: Paidós, 2001. Impreso.

Dyhouse, Carol. Glamour. Mujeres, historia y feminismo. Argentina: Claridad, 2011. Impreso.

Eco, Umberto. Historia de la belleza. Barcelona: Debolsillo, 2010. Impreso.

Edwards Bello, Joaquín. La chica del Crillón. Santiago de Chile: Universitaria, 2006. Impreso.

Eliot, Maxine. "Charla". La Semana Cinematográfica 18 (5 septiembre de 1918): 6. Impreso.

Entwistle, Joanne. El cuerpo y la moda. Una visión sociológica. Barcelona: Paidós, 2002. Impreso.

Faúndez, Pablo. "La revista Zig-Zag y el arribo del cine a Chile (1905-1940)". Mapocho 71 (2012): 329-339. Impreso.

Gallego, Juana. Mujeres de papel. De ¡Hola! A Vogue: la prensa femenina en la actualidad, Barcelona: Tesys, 1990. Impreso.

Gil Calvo, Enrique. Medias miradas. Un análisis cultural de la imagen femenina. Barcelona: Anagrama, 2000. Impreso.

Góngora, Álvaro. "De jardín privado a balneario público. Veraneando en Viña del Mar”. Rafael Sagredo y Cristián Gazmuri. Historia de la vida privada en Chile, tomo II. Santiago: Taurus, 2006. 305-331. Impreso.

Gubern, Román. Historia del cine. Editor digital: Titivilus, 2014. Impreso.

Gundle, Stephen. Glamour. A history. Gran Bretaña: Oxford University Press, 2008. Impreso.

Gundle, Stephen y Clino Castelli. The Glamour System. Nueva York: Palgrave MacMillan, 2006. Impreso.

Iturriaga, Jorge. La masificación del cine en Chile, 1907-1932. La conflictiva construcción de una cultura plebeya. Santiago: Lom, 2015. Impreso.

Jodelet, Denise. "La representación social: fenómenos, conceptos y teoría". Psicología social II. Comp. Serge Moscovici. Barcelona: Paidós, 1984. 469-494. Impreso.

---. "Representaciones sociales: contribución a un saber sociocultural sin frontera". Develando la Cultura. Estudios en representaciones sociales. Coord. Denise Jodelet y Alfredo Guerrero. México DF: Universidad Nacional Autónoma de México, 2000. 7-30. Impreso.

Kaczcan, Gisela Paola. "Salud, belleza, aire libre. Montaje de la apariencia femenina a orillas del mar (circa 1920-1940)”. Arenal 20 (2013): 129-157. Impreso.

Lipovetsky, Gilles. El imperio de lo efímero. La moda y su destino en las sociedades modernas. Barcelona: Anagrama, 1990. Impreso.

"La esbeltez de las muchachas de Hollywood". Ecran 5 (3 jun 1930): 24-25. Impreso.

"Las estrellas del cine orientan la moda". Ecran 2 (22 abr 1930): 4. Impreso.

"Los deportes y las estrellas jóvenes". Ecran 3 (6 may 1930): 17-18. Impreso.

Méndez, María Isabel. "Aproximación teórica al concepto de prensa femenina”. Comunicación y Sociedad 2 (2009): 227-297. Impreso. 
Montalva, Pía. "La vida elegante. Mujeres y distinción en Chile, 1900-1940”. Historia de las mujeres en Chile, tomo 2. Ana María Stuven y Joaquín Fermandois. Santiago: Taurus, 2013. Impreso.

---. Morir un poco. Moda y sociedad en Chile 1960-1976. Santiago: Catalonia, 2015. Impreso.

Montero, Claudia. "Prensa de mujeres en el circuito comercial en Chile entre 1900 y 1920”. Argos 62 (2015): 57-76. Impreso.

Moreno, Paz. "Hacer cuerpo: gordura femenina y empoderamiento". Hysteria 9 (2015). Web. 11 Oct. 2015. Impreso.

Morin, Edgar. Las estrellas del cine. Buenos Aires: Eudeba, 1964. Impreso.

Mouesca, Jacqueline. El cine en Chile. Crónica en tres tiempos. Santiago: Planeta, 1997. Impreso.

Mouesca, Jacqueline y Carlos Orellana. Breve historia del cine chileno. Desde sus orígenes hasta nuestros días. Santiago: Lom, 2010. Impreso.

Mulvey, Laura. "Visual Pleasure and narrative cinema". Film Theory and Criticism: Introductory Readings. Eds. Leo Braudy y Marshall Cohen. Nueva York: Oxford University Press, 1999. 833-844. Impreso.

Ossandón, Carlos. “Zig-Zag o la imagen como gozo”. Entre las alas y el plomo. La gestación de la prensa moderna en Chile. Carlos Ossandón y Eduardo Santa Cruz. Santiago: Lom/ Universidad ARCIS/DIBAM, 2001. 61-78. Impreso.

---. "Los mudos rostros del cine en Chile". Aisthesis 41 (2007): 117-130. Impreso.

Prats de Ortúzar, Rosa. La mujer su actuación en el hogar. Santiago: Imprenta Chile, 1924. Impreso.

Purcell, Fernando. "Una mercancía irresistible. El cine norteamericano y su impacto en Chile, 1910-1930”. Historia crítica 38 (2009): 46-69. Impreso.

---. jDe película! Hollywood y su impacto en Chile 1910-1950. Santiago: Taurus, 2012. Impreso.

Queirolo, Graciela. "Vendedora: género y trabajo en el sector comercial (Buenos Aires, 1910-1950)". Estudos Feministas 22 (2014). 29-50. Impreso.

R. C. “Triunfo y decadencia de las piernas”. Ecran 7 (1 julio 1930): 9. Impreso.

Ramos, María José. “Cine y moda. Desde los orígenes hasta la década de los treinta”. Revista Latente 4 (2006): 153-177. Impreso.

Retratos de Mujer 1880-1920. Chile. Rostros, poses, vestimenta y modas del ser femenino, Santiago: Museo Histórico Nacional de Chile, 2010. Impreso.

Reyes, Claudia. "Imagen, mujer y cultura: Desterritorialización y apropiación de imágenes del Star System”. Nexus Comunicación 13 (2013): 68-85. Impreso.

Rinke, Stefan. Cultura de masas: reforma y nacionalismo en Chile 1910-1931. Santiago: Centro de Estudios Barros Arana/DiBAM, 2002. Impreso.

---. Encuentros con el yanqui. Norteamericanización y cambio sociocultural en Chile 1898-1990. Santiago: DiBAM/Centro de Investigaciones Diego Barros Arana, 2013. Impreso. 
Salazar, Gabriel. Patriarcado mercantil y liberación femenina (1810-1930). Santiago: Lom/ SERnAM, 2010. Impreso. Impreso.

Salazar, Gabriel y Julio Pinto. Historia Contemporánea de Chile IV. Hombría y Feminidad. Santiago: Lom, 2002. Impreso.

Salomó, Jorge. La Belle époque viñamarina a través de la caricatura del Mundo. Valparaíso: Ediciones Universitarias de Valparaíso, 2011. Impreso.

Santa Cruz, Eduardo. "Las revistas de cine (1910-1920)". Entre las alas y el plomo. La gestación de la prensa moderna en Chile. Carlos Ossandón y Alberto Santa Cruz. Santiago: Lom/ARCIS/DIBAM, 2001: 213-245. Impreso.

---. "Cultura de masas y espacio público en Chile: las revistas de cine (1910-1930)”. Comunicación y Medios 15 (2004): 139-155. Impreso.

---. "El nuevo arte de la oscuridad el cine en la sociedad chilena a comienzos del siglo Xx". Mapocho 58 (2005): 203-226. Impreso.

Scott, Joan. "El Género: una categoría útil para el análisis histórico". Género e historia. México: Fondo de Cultura Económica/ Universidad Autónoma de la Ciudad de México, 2008. 48-74. Impreso.

Serafini, Frank. "Expanding perspectives for comprehending visual images in multimodal texts". Journal of adolescent \& adult literacy 54 (2011): 342-350. Impreso.

Traversa, Oscar. Cuerpos de papel. Figuraciones del cuerpo en la prensa 1918-1940. Barcelona: Gedisa, 1997. Impreso.

Vaquero, Isabel. "El reinado de la Alta Costura: la moda de la primera mitad del siglo xx”. Indumenta: Revista del Museo del Traje 0 (2007): 123-134. Impreso.

Vicuña Urrutia, Manuel. La belle époque chilena. Alta sociedad y mujeres de elite en el cambio de siglo. Santiago: Sudamericana, 2001. Impreso.

Vigarello, Georges. Historia de la belleza. El cuerpo y el arte de embellecer desde el Renacimiento hasta nuestros días. Buenos Aires: Nueva Visión, 2009. Impreso.

Recibido: 10 junio 2016

Aceptado: 20 septiembre 2016 